\title{
PENGARUH KOMPENSASI DAN DISIPLIN KERJA TERHADAP KEPUASAN KERJA KARYAWAN PT ASTRA INTERNATIONAL DAIHATSU, TBK CABANG NAROGONG
}

\author{
Agung Bagus Wijayanto ${ }^{1)}$ \\ 1) Mahasiswa Program Studi Manajemen FE UNKRIS \\ Ahmad Hermanto ${ }^{2)}$ \\ 2) Dosen Program Studi Manajemen FE UNKRIS \\ Alamat: Kampus UNKRIS, Jatiwaringin Jakarta Timur \\ Email: hermanto.unkris@gmail.com
}

\begin{abstract}
The purpose of this study was to determine the effect of compensation and work discipline on job satisfaction of employees PT. Astra International Daihatsu, Tbk Narogong. The research method uses qualitative and quantitative descriptive analysis, the analysis model used is linear regression both simply and multiple. The study population of all employees of PT. Astra International Daihatsu, Tbk Narogong with 93 employees. The technique used is simple random sampling using Slovin formula obtained a sample of 75 employees. Result compensation and work discipline have a positive and significant effect on job satisfaction of employees of PT. Astra International Daihatsu, Tbk Narogong both partially and simultaneous.
\end{abstract}

Keywords: Compensation, work discipline and job satisfaction of employees

\section{PENDAHULUAN}

Dalam era persaingan global, perusahaan-perusahaan membutuhkan kinerja yang tinggi dari para karyawannya. Untuk tetap bertahan dan sukses, perusahaan harus tetap berkompetisi pada lingkungannya. Perusahaan mempertahankan kompetensi melalui pengembangan sumber daya manusia yang tidak pernah berhenti. Apapun produk perusahaan, baik barang maupun jasa/pelayanan, peranan manusia menempati urutan terpenting untuk menghasilkan produk bermutu dan memuaskan. Perusahaan bisa saja memiliki teknologi yang sangat canggih, dana yang berlebihan, sistem, serta prosedur yang baik, akan tetapi tanpa manusia yang berkualitas dalam segala aspek, hasil yang diinginkan tidak akan dapat dicapai.

Industri otomotif merupakan sektor usaha yang berfungsi untuk memberikan kebutuhan kendaraan pribadi bagi masyarakat. Dengan kesibukan masyarakat sekarang ini yang menuntut masyarakat untuk dapat meningkatkan mobilitasnya. Untuk dapat memenuhi kebutuhan tersebut, sarana kendaraan pribadi yang sesuai dengan kebutuan setiap individu masyarakat menjadi peluang tersendiri dari bisnis industri otomotif.

PT. Astra International Tbk. Produsen (Pabrik) kendaraan Daihatsu di Indonesia diproduksi oleh PT.Astra Daihatsu Motor (ADM), merupakan Agen Pemegang Merek Daihatsu di Indonesia sekaligus Produsen (Pabrik) kendaraan merek Daihatsu selalu berusaha untuk memberikan pelayanan terbaik kepada pelanggan. Untuk mendukung efisiensi kerja perusahaan dan pelayanan kepada para konsumen diperlukan sumber daya manusia yang berkulitas tinggi.

Sumber daya manusia memiliki peranan penting dalam operasional perusahaan yang 
dituntut untuk lebih memperhatikan aspek sumber daya manusia yang dimilikinya agar dapat tercipta karyawan yang profesional, tangguh, cerdas, dan berpandangan kedepan yang diharapkan dapat memberikan kontribusi yang besar terhadap kemajuan peusahaan. Jika sumber daya manusia tidak diperhatikan oleh perusahaan, maka akan terjadi menurunnya kepuasan kerja karyawan.

Handoko (2012), mengemukakan bahwa kepuasan kerja (Job Satisfaction) adalah "keadaan emosional yang menyenangkan atau tidak menyenangkan dengan para karyawan memandang pekerjaan mereka. Waktu/lama penyelesaian merupakan pencerminan perasaan seseorang terhadap pekerjaannya. Ini dapat dilihat dari sikap positif karyawan terhadap pekerjaan dan segala sesuatu di lingkungannya".

Kepuasan kerja adalah perasaan seseorang terhadap pekerjaannya. Ini berarti bahwa konsepsi kepuasan kerja melihatnya sebagai hasil interaksi manusia terhadap lingkungan kerjanya. Di samping itu, perasaan seseorang terhadap pekerjaan tentulah sekaligus merupakan refleksi dari sikapnya terhadap pekerjaan. Pada dasarnya kepuasan kerja merupakan hal yang bersifat individual. Setiap individu akan memiliki tingkat kepuasan yang berbeda-beda sesuai dengan sistem nilai-nilai yang berlaku dalam dirinya. Ini disebabkan karena adanya perbedaan pada masing-masing individu. Semakin banyak aspek-aspek dalam pekerjaan yang sesuai dengan keinginan individu, maka akan semakin tinggi tingkat kepuasan yang dirasakan, dan sebaliknya.

Permasalahan puas dan ketidakpuasan dari karyawan terhadap perusahaan, umumnya terjadi akibat pemberian kompensasi berupa upah/gaji, insentif yang tidak sesuai dengan apa yang diharapkan karyawan. Kompensasi adalah semua imblan yang diterima oleh seorang pekerja atas jasa atau hasil kerjanya pada sebuah perusahaan. maka pemberian kompensasi berupa finansial dan juga nonfinansial kepada karyawan sangat penting untuk diupayakan oleh perusahaan.

Hasibuan (2013), menyampaikan kompensasi adalah "semua pendapatan yang berbentuk uang, barang langsung ataupun tidak langsung yang diterima karyawan dalam bentuk imbalan atas jasa yang diberikan kepada perusahaan". Perusahaan yang perduli dengan keberadaan karyawannya selalu akan memperhatikan kompensasi yang cukup baik, dari tunjangan yang diberikan perusahaan kepada karyawan atau pekerja yang memberikan jasanya kepada suatu perusahaan. gaji, upah, bonus, atau lainnya yang diberikan untuk dapat meningkatkan disiplin kerja karyawan, membangun karir mereka dan memastikan bahwa mereka berkomitmen dalam mencapai tujuan perusahaan.

Disiplin kerja juga tidak kalah penting dalam mempengaruhi kepuasan kerja karyawan. Disiplin kerja yaitu suatu sikap dan perilaku seseorang yang menunjukkan ketaatan, kepatuhan, kesetiaan, keteraturan dan ketertiban pada peraturan perusahaan atau organisasi dan norma-normal sosial yang berlaku. Rivai (2011), menyebutkan disiplin kerja adalah "suatu alat yang dipergunakan para manajer untuk berkomunikasi dengan karyawan agar mereka bersedia untuk mengubah suatu perilaku serta sebagai suatu upaya untuk meningkatkan kesadaran dan kesediaan seorang dalam memenuhi segala peraturan perusahaan". Disiplin kerja merupakan unsur terpenting yang harus dimiliki seseorang dalam mengikuti semua aturan yang diterapkan oleh perusahaan. Sebab tanpa disiplin yang baik maka akan terjadi penurunan hasil kerja yang tidak maksimal tentunya akan berdampak pada tujuan dari perusahaan. Manusia sendirilah yang dapat menentukan tingkat disiplin kerja yang dapat berperan penting dalam dunia kerja. 
Tabel 1 Rekapitulasi Kehadiran Karyawan

Periode Januari - Oktober 2019

\begin{tabular}{lccccc}
\hline \multicolumn{1}{c}{ Bulan } & Jumlah & Kehadiran & Ijin & Sakit & Tanpa Alasan \\
\hline Januari & 93 & 87 & 2 & 3 & 1 \\
Pebruari & 93 & 90 & 1 & 1 & 1 \\
Maret & 93 & 89 & 1 & 2 & 1 \\
April & 93 & 85 & 3 & 2 & 0 \\
Mei & 93 & 86 & 2 & 3 & 2 \\
Juni & 93 & 85 & 2 & 4 & 2 \\
Juli & 93 & 87 & 4 & 1 & 1 \\
Agustus & 93 & 91 & 1 & 1 & 0 \\
September & 93 & 88 & 1 & 3 & 1 \\
Oktober & 93 & 90 & 0 & 3 & 0 \\
\hline Jumlah & $\mathbf{9 3 0}$ & $\mathbf{8 7 8}$ & $\mathbf{1 7}$ & $\mathbf{2 3}$ & $\mathbf{9}$ \\
\hline Sumber: & A & &
\end{tabular}

Sumber: PT. Astra International, Tbk tahun 2019

Dengan melihat Tabel 1, terbukti bahwa tingkat disiplin kerja karyawan PT. Astra International Tbk Cabang Narogong relative masih normal, dimana pada tahun 2019 frekuensi izin (17 orang) dan sakit (23 orang). Hal tersebut berpengaruh pada tidak tercapainya beberapa poin dari key performance indicator pada tahun 2018.

PT. Astra International Tbk - Daihatsu Sales Operation (AI-DSO) Cabang Narogong berdiri sejak tahun 1973. AI-DSO sebagai salah satu perusahaan otomotif terbesar yang bergerak dan bertanggung jawab di bidang distribusi, penjualan, dan after sales service kendaraan bermerek Daihatsu yang manajemennya ditangani penuh oleh PT. Astra International Tbk. Produsen (Pabrik) kendaraan daihatsu di indonesia diproduksi oleh PT.Astra Daihatsu Motor (ADM), merupakan Agen Pemegang Merek Daihatsu di indonesia sekaligus Produsen (Pabrik) kendaraan merek Daihatsu. Daihatsu terus membangun dirinya menjadi merek global yang dicintai di seluruh dunia dan perusahaan yang memiliki kepercayaan diri dan kebanggaan, melalui produksi mobil yang inovatif, hemat dan terkemuka di setiap era. Slogan baru "Innovation for Tomorrow" menjadi komitmen perusahaan untuk selalu mewujudkan inovasi dengan menghasilkan produk-produk berkualitas tinggi yang dapat memberikan manfaat bagi masyarakat luas dan ramah lingkungan.

Masalah tenaga kerja merupakan salah satu faktor yang penting bagi perusahaan, sehingga dengan pemberian kompensasi yang sesuai, adil dan layak serta disiplin kerja karyawan dengan baik merupakan cara untuk dapat meningkatkan kepuasan kerja karyawan sesuai tujuan perusahaan.

Tujuan penelitian ini adalah untuk mengetahui "pengaruh kompensasi dan disiplin kerja terhadap kepuasan kerja karyawan PT. Astra International Daihatsu, Tbk Cabang Narogong“.

\section{LANDASAN TEORI}

\section{Kepuasan Kerja}

Kepuasan kerja adalah Kondisi psikis yang menyenangkan yang dirasakan oleh pekerja/karyawan di dalam suatu lingkungan pekerjaan atas peranannya dalam organisasi dan kebutuhannya terpenuhi dengan baik.

Kreitner dan Kinicki (2014), bahwa "kepuasan kerja sebagai efektivitas atau respons emosional terhadap berbagai aspek pekerjaan". (Robbins \& Judge, 2008), menyebutkan 
kepuasan kerja "suatu perasaan positif tentang pekerjaan seseorang yang merupakan hasil dari sebuah evaluasi karakteristiknya". Luthans, (2012), menyampaikan kepuasan kerja adalah "hasil dari persepsi karyawan mengenai seberapa baik pekerjaan mereka memberikan hal yang dinilai penting".

Sutrisno, (2011), menyampaikan Faktor-faktor yang dapat mempengaruhi kepuasan kerja adalah: 1). "Kesempatan untuk maju; Dalam hal ini, ada tidaknya kesempatan untuk memperoleh pengalaman dan peningkatan kemampuan selama kerja. 2). Keamanan kerja; Faktor ini disebut sebagai penunjang kepuasan kerja, baik bagi karyawan. Keadaan yang aman sangat mempengaruhi perasaan karyawan selama kerja. 3). Gaji; Gaji lebih banyak menyebabkan ketidakpuasan, dan jarang orang mengekspresikan kepuasan kerjanya dengan sejumlah uang yang diperolehnya. 4). Perusahaan dan manajemen; Perusahaan dan manajemen yang baik adalah yang mampu memberikan situasi dan kondisi kerja yang stabil. 5). Pengawasan; Sekaligus atasannya. Supervisi yang buruk dapat berakibat absensi dan turnover. 6). Faktor Intrinsik dari pekerjaan; Atribut yang ada dalam pekerjaan mensyaratkan keterampilan tertentu. Sukar dan mudahnya serta kebanggaan akan tugas dapat meningkatkan atau mengurangi kepuasan. 7). Kondisi kerja; Termasuk di sini kondisi kerja tempat, ventilasi, penyiaran, kantin dan tempat parkir. 8). Aspek sosial dalam pekerjaan; Merupakan salah satu sikap yang sulit digambarkan tetapi dipandang sebagai faktor yang menunjang puas atau tidak puas dalam bekerja. 9). Komunikasi. Komunikasi yang lancar antar karyawan dengan pihak manajemen banyak dipakai alasan untuk menyukai jabatannya. Dalam hal ini adanya kesediaan pihak atasan untuk mau mendengar, memahami dan mengakui pendapat ataupun prestasi karyawannya sangat berperan dalam menimbulkan rasa puas terhadap kerja. 10). Fasilitas; Fasilitas rumah sakit, cuti, dana pensiun, atau perumahan merupakan standar suatu jabatan dan apabila dapat dipenuhi akan menimbulkan rasa puas".

Jika perusahaan mampu mempengaruhi kepuasan kerja maka akan memperoleh banyak sekali manfaat. Menurut Nitisemito (2010) manfaat kepuasan kerja adalah sebagai berikut: 1). "Pekerjaan akan lebih cepat diselesaikan; 2). Kerusakan akan dapat dikurangi; 3). Absensi dapat diperkecil; 4). Perpindahan karyawan dapat diperkecil; 5). Produktivitas kerja dapat ditingkatkan; 6). Ongkos per unit dapat diperkecil”.

Hasibuan (2013), mengemukakan indikator kepuasan kerja seorang karyawan dapat dilihat dari beberapa hal berikut ini: 1). "Menyenangi Pekerjaannya; Karyawan sadar arah yang ditujunya, punya alasan memilih tujuannya, dan mengerti cara dalam bekerja. Dengan kata lain, seorang karyawan menyenangi pekerjaannya karena ia bisa mengerjakannya dengan baik. 2). Mencintai Pekerjaannya; Dalam hal ini karyawan tidak sekedar menyukai pekerjaannya tapi juga sadar bahwa pekerjaan tersebut sesuai dengan keinginannya. 3). Moral Kerja Positif; Ini merupakan kesepakatan batiniah yang muncul dari dalam diri seseorang atau organisasi untuk mencapai tujuan tertentu sesuai dengan mutu yang ditetapkan. 4). Disiplin Kerja; Kondisi yang tercipta dan terbentuk melalui proses dari serangkaian perilaku yang menunjukkan nilai-nilai ketaatan, kepatuhan, kesetiaan, keteraturan dan atau ketertiban. 5). Prestasi Kerja; Hasil kerja yang dicapai seseorang dalam melaksanakan tugas-tugas yang dibebankan kepadanya yang didasarkan atas kecakapan dan kesungguhan serta waktu".

\section{Kompensasi}

Kompensasi adalah semua imbalan yang diterima oleh seorang pekerja atas jasa atau hasil kerjanya pada sebuah organisasi/ perusahaan dimana imbalan tersebut dapat berupa uang ataupun barang, baik langsung ataupun tidak langsung.

Sedarmayanti (2017), menyampaikan kompensasi adalah "segala sesuatu yang di 
terima oleh karyawan sebagai balas jasa kerja mereka". Umar (2007), menyebutkan kompensasi adalah "segala sesuatu yang diterima oleh karyawan, baik itu berupa gaji, upah, insentif, bonus, premi, pengobatan, asuransi dan lain-lain, dan sejenisnya yang di bayar langsung perusahaan". Wibowo (2011), menyampaikan kompensasi adalah "kontra prestasi terhadap penggunaan tenaga atau jasa yang telah diberikan oleh tenaga kerja kepada perusahaan". Handoko (2012), mengemukakan kompensasi adalah "segala sesuatu yang diterima para karyawan sebagai balas jasa untuk kerja mereka".

Dari beberapa pendapat tersebut dapat disimpulkan bahwa kompensasi yang diberikan pada karyawan tidak hanya berbentuk uang, tetapi dapat berupa barang dan jasa pelayanan. Kompensasi diberikan kepada setiap karyawan yang telah bekerja dalam suatu perusahaan sebagai timbal balik atas pekerjaan yang telah dilakukan oleh karyawan tersebut. Tingkat kompensasi yang diberikan dapat mempengaruhi kepuasan kerja karyawan dalam meningkatkan produktivitas.

Menurut Yani (2012), menjelaskan bahwa kompensasi dibedakan menjadi dua bentuk, yaitu: 1). "Kompensasi dalam bentuk Finansial; Kompensasi finansial dibagi menjadi dua bagian, yaitu kompensasi finansial yang dibayarkan secara langsung seperti gaji, upah, komisi dan bonus. Kompensasi finansial yang diberikan secara tidak langsung, seperti tunjangan kesehatan, tunjangan pensiun, tunjangan hari raya, tunjangan perumahan, tunjangan pendidikan dan lain sebagainya. 2). Kompensasi dalam bentuk non finansial; Kompensasi dalam bentuk non finansial dibagi menjadi dua macam, yaitu yang berhubungan dengan pekerjaan dan yang berhubungan dengan lingkungan kerja. Yang berhubungan dengan pekerjaan, misalnya kebijakan perusahaan yang sehat, pekerjaan yang sesuai (menarik, menantang), peluang untuk dipromosikan, mendapat jabatan sebagai simbol status. Sedangkan kompensasi non finansial yang berhubungan dengan lingkungan kerja, seperti ditempatkan dilingkungan kerja yang kondusif, fasilitas kerja yang baik dan lain sebagainya".

Pemberian sebuah kompensasi terhadap karyawan pasti memiliki tujuan positif. Menurut Notoatmodjo, (2009), tujuan dari kebijakan pemberian kompensasi meliputi: 1). "Penghargaan terhadap prestasi karyawan; 2). Menjamin keadilan gaji karyawan; Mempertahankan karyawan atau mengurangi turnover karyawan; 3). Memperoleh karyawan yang bermutu; 4). Pengendalian biaya; 5). Memenuhi peraturan-peraturan.

Simamora (2012), menyatakan indikator untuk mengukur kompensasi karyawan diantaranya adalah: 1). "Upah atau Gaji; Upah biasanya berhubungan dengan tarif gaji per jam (semakin lama kerjanya, semakin besar upahnya). Upah merupakan basis pembayaran yang kerap digunakan bagi pekerja-pekerja produksi dan pemeliharaan. Sedangkan gaji umumnya berlaku untuk tarif mingguan, bulanan atau tahunan. 2). Insentif; Insentif merupakan tambahan-tambahan gaji di atas atau di luar gaji atau upah yang diberikan oleh organisasi. Program-program insentif disesuaikan dengan memberikan bayaran tambahan berdasarkan produktivitas, penjualan, keuntungan-keuntungan, atau upaya-upaya pemangkasan biaya. 3). Tunjangan; Contoh tunjangan dalam perusahaan biasanya meliputi asuransi kesehatan, asuransi jiwa, liburan-liburan yang ditanggung perusahaan, program pensiun, dan tunjangan-tunjangan lainnya yang berhubungan dengan kepegawaian. 4). Fasilitas; Kenikmatan atau fasilitas seperti mobil perusahaan, keanggotaan klub, tempat parkir khusus, dan lain sebagainya".

\section{Disiplin Kerja}

Disiplin merupakan sikap, tingkah laku dan perbuatan yang sesuai dengan peraturan perusahaan baik yang tertulis maupun yang tidak tertulis. Peraturan yang dimaksud termasuk absensi, lambat masuk, serta cepat pulang karyawan. Jadi hal ini merupakan suatu 
sikap indisipliner karyawan yang perlu disikapi dengan baik oleh pihak manajemen.

Banyak yang mengartikan disiplin itu harus karyawan selalu datang serta pulang tepat pada waktunya. Pendapat itu hanya salah satu yang dituntut oleh organisasi. Oleh karena itu "kedisiplinan dapat diartikan sebagai tingkah laku yang tertulis maupun yang tidak tertulis". (Hasibuan, 2013).

Menegakkan suatu kedisiplinan penting bagi perusahaan, sebab kedisiplinan berisikan peraturan-peraturan yang harus ditaati karyawan. Dengan kedisiplinan diharapkan dapat membuat pekerjaan seefisien mungkin. Disiplin kerja dapat dilihat sebagai sesuatu yang besar manfaatnya, baik bagi kepentingan organisasi maupun bagi para karyawan. Bagi organisasi adanya disiplin kerja akan menjamin terpeliharanya tata tertib dan kelancaran pelaksanaan tugas, sehingga diperoleh hasil yang optimal. Sedangkan bagi karyawan akan diperoleh suasana kerja yang menyenangkan sehingga akan menambah semangat kerja dalam melaksanakan pekerjaannya. Dengan demikian, karyawan dapat melaksanakan tugasnya dengan penuh kesadaran serta dapat mengembangkan tenaga dan pikirannya semaksimal mungkin demi terwujudnya tujuan perusahaan.

Kedisiplinan dalam suatu perusahaan dapat ditegakkan bilamana sebagian besar peraturan-peraturannya ditaati para anggota perusahaan tersebut. Menurut Moekijat (2010) tujuan utama dari disiplin adalah "untuk mendorong karyawan berprilaku sepantasnya ditempat kerja, dimana prilaku yang sepantasnya ditetapkan sebagai kepatuhan terhadap peraturan dan prosedur berfungsi sama dengan peraturan undang - undang masyarakat". Disiplin kerja dapat dilihat sebagai sesuatu yang besar manfaatnya, baik bagi kepentingan organisasi maupun bagi para karyawan. Bagi perusahaan adanya disiplin kerja akan menjamin terpeliharanya tata tertib dan kelancaran pelaksanaan tugas, sehingga diperoleh hasil yang optimal. Sedangkan bagi karyawan akan diperoleh suasana kerja yang menyenangkan sehingga akan menambah semangat kerja dalam melaksanakan pekerjaannya. Dengan demikian, karyawan dapat melaksanakan tugasnya dengan penuh kesadaran serta dapat mengembangkan tenaga dan pikirannya semaksimal mungkin demi terwujudnya tujuan perusahaan.

Menurut Saydam (2011). Manfaat dari penerapan disiplin kerja yang akan terlihat pada : 1). "Tingginya rasa kepedulian karyawan terhadap pencapaian tujuan perusahaan. 2). Tingginya semangat dan gairah kerja para karyawan dalam melakukan pekerjaannya. 3). Berkembangnya rasa memiliki dan kesetiakawanan yang tinggi di kalangan karyawan. 4). Besarnya tanggung jawab para karyawan melaksanakan tugas dengan sebaik-baiknya. 5). Meningkatnya efisiensi dan produktivitas para karyawan.

Hasibuan (2013) faktor-faktor yang mempengaruhi disiplin kerja karyawan adalah sebagai berikut: 1). "Tujuan dan kemampuan; Tujuan dan kemampuan ikut mempengaruhi tingkat kedisiplinan karyawan, tentu saja pada dasarnya pekerjaan yang dibebankan kepada karyawan harus sesuai dengan kemampuan karyawan tersebut, agar karyawan tersebut disiplin dan bersungguh-sungguh dalam mengerjakan pekerjaannya. 2). Kepemimpinan; Kepemimpinan sangat memiliki peranan penting dalam menentukan kedisiplinan kerja karyawan. Karena pemimpin tersebut akan menjadi contoh bagi para bawahannya. 3). Kompensasi; Kompensasi sangat berperan penting terhadap kedisiplinan kerja karyawan, artinya semakin besar kompensasi yang diberikan perusahaan, naka senakin baik disiplin kerja karyawan. Begitu juga sebaliknya, karyawan akan sulit bekerja dengan disiplin jika kebutuhan primer mereka tidak terpenuhi. 4). Sanksi hokum; Sanksi hukum yang semakin berat akan membuat karyawan takut untuk melakukan tindakan indisipliner, dan ketaatan karyawan terhadap peraturan perusahaan akan semakin baik. 5). Pengawasan; Pengawasan adalah tindakan yang paling efektif untuk mewujudkan kedisiplinan kerja karyawan tersebut". 
Pada dasarnya banyak indikator yang mempengaruhi tingkat kedisiplinan karyawan suatu perusahaan, diantaranya yang disampaikan oleh Moenir (2014). Indikator - indikator yang mempengaruhi disiplin kerja: 1). "Ketepatan Waktu; Ketepatan waktu dalam pekerjaan dan tugas, meliputi: a). Ketepatan waktu dalam melaksanakan tugas. b). Penghematan waktu dalam melaksanakan tugas. 2). Tanggung Jawab; Tanggungjawab dalam pekerjaan dan tugas, meliputi: a). Melakukan pekerjaan sesuai dengan rencana. b). Mengevaluasi hasil pekerjaan. c). Keberanian menerima resiko kesalahan. 3). Ketaatan; Ketaatan terhadap peraturan yang telah ditetapkan, meliputi: a). Ketaatan terhadap jam kerja. b). Ketaatan terhadap pimpinan. c). Ketaatan terhadap prosedur dan metode kerja".

\section{METODE PEELITIAN}

Penelitian dilakukan pada PT. Astra International Daihatsu, Tbk, Cabang Narogong, Jalan Raya Siliwangi No. 117 Sepanjang Jaya, Rawalumbu Bekasi. Metode penelitian yang digunakan adalah metode penelitian kuantitatif dengan jumlah sampel 75 orang. Data dikumpulkan dengan menggunakan metode kuesioner, dan teknik analisis data yang digunakan adalah analisis regresi linier berganda dan sederhana.

\section{HASIL PENELITIAN DAN PEMBAHASAN}

\section{Hasil Penelitian \\ Uji Instrumen Data}

Untuk dapat menentukan apakah benar variabel kompensasi dan disiplin kerja dapat dijadikan pengukur terhadap kepuasan kerja karyawan PT. Astra International Daihatsu, Tbk, Cabang Narogong, namun sebelum data diolah terlebih dahulu dilakukan pengujian terhadap variabel yang di gunakan yaitu kompensasi, disiplin kerja dan kepuasan kerja untuk mengetahui apakah data tersebut akurat dan dapat dipercaya. Untuk lebih jelasnya maka dibawah ini dapat kita lihat hasil dari survei, sebagai berikut:

\section{Uji Validitas}

Penguji validitas ini dilakukan untuk menguji apakah tiap-tiap butir pernyataan telah mewakili indikator yang akan diselidiki. Uji validitas dilakukan dengan melihat korelasi anatar skor masing-masing item pernyataan dengan skor total.

Dari hasil perhitungan korelasi skor tiap butir pernyataan kompensasi, disiplin kerja dan kepuasan kerja dari 75 responden dengan jumlah pernyataan masing-masing variabel 8 pernyataan untuk kompensasi, 9 pernyataan untuk disiplin kerja dan 10 pertanyaan untuk kepuasan kerja dengan total skor setiap perusahaan diperoleh hasil bahwa dari 8 butir pernyataan dari variabel kompensasi, 9 pernyataan disiplin kerja dan 10 pertanyaan kepuasan kerja karyawan hasilnya adalah valid.

\section{Uji Reliabiltas}

Selanjutnya dilakukan uji reliabilitas untuk mengetahui sejauh mana hasil pengukurannya dapat diandalkan dan konsisten. Pada Tabel 2 hasil pengujian berikut diketahui bahwa semua variabel mempunyai alpha di atas 0.60 yang berarti bahwa semua variabel dalam penelitian ini dapat diandalkan. 
Tabel 2. Hasil Uji Reliabilitas

\begin{tabular}{lccc}
\hline \multicolumn{1}{c}{ Variabel } & $\begin{array}{c}\text { Cronbach } \\
\text { Alpha }\end{array}$ & $\begin{array}{c}\text { Nilai kritis } \\
(\boldsymbol{\alpha})=\mathbf{5 \%}\end{array}$ & Keterangan \\
\hline Kompensasi & 0.608 & 0.600 & Reliabel \\
Disiplin Kerja & 0.775 & 0.600 & Reliabel \\
Kepuasan Kerja & 0.610 & 0.600 & Reliabel \\
\hline
\end{tabular}

Sumber: data diolah tahun 2020

Berdasarkan angka-angka reliabilitas cronbach alpha tersebut tampak bahwa seluruh pernyataan yang ada membentuk ukuran yang reliabel, yaitu kompensasi, disiplin kerja, dan kepuasan kerja membentuk ukuran yang reliabel dari masing-masing variabel

\section{Analisis Regresi Linear Sederhana}

Tabel 3. Pengaruh Kompensasi Terhadap Kepuasan Kerja

\begin{tabular}{lccccc}
\hline \multirow{2}{*}{ Variabel } & $\begin{array}{c}\mathbf{R} \\
\text { Square }\end{array}$ & $\begin{array}{c}\text { Konst } \\
\text { anta }\end{array}$ & $\begin{array}{c}\text { Koefisien } \\
\text { Regresi }\end{array}$ & Sig & $\boldsymbol{\alpha}$ \\
\hline Kompensasi & 0,696 & 12,112 & 0,924 & 0,000 & 0,05 \\
\hline Pengujian Signifikan & & & & \\
\hline t hitung $>$ t tabel $=12,930>1,993$ & & &
\end{tabular}

Keterangan: Variabel Kepuasan Kerja

Sumber : data diolah 2020

Berdasarkan Tabel 3, nilai koefisien determinasi $\left(\mathrm{R}^{2}\right)$ sebesar 0.696, artinya kompensasi memberikan kontribusi sebesar 69,6\% kepada kepuasan kerja karyawan PT Astra International Tbk Daihatsu, Tbk Cabang Narogong, sedangkan sisanya sebesar 30,4\% disumbangkan faktor lain yang tidak diteliti, seperti disiplin kerja.

$$
\text { Persamaan Regresi Y = 12,112 + 0,924 }\left(\mathrm{X}_{1}\right)
$$

Kompensasi berpengaruh positif dan signifikan pada tingkat nyata 99\% terhadap kepuasan kerja karyawan PT Astra International Tbk Daihatsu, Tbk Cabang Narogong. Koefisien kompensasi sebesar 0,924, artinya jika ada peningkatan kompensasi satu kali, maka kepuasan kerja karyawan PT Astra International Tbk Daihatsu, Tbk Cabang Narogong akan meningkat sebesar 0,924 kali atau sebaliknya. Nilai t hitung >t tabel $(12,930>1,993)$, maka Ho tolak, Ha terima, artinya ada pengaruh yang positif dan signifikan kompensasi terhadap kepuasan kerja karyawan PT Astra International Tbk Daihatsu, Tbk Cabang Narogong.

Tabel 4. Pengaruh Disiplin Kerja Terhadap Kepuasan Kerja

\begin{tabular}{lccccc}
\hline & \multicolumn{5}{c}{ Parameter } \\
\cline { 2 - 6 } Variabel & $\begin{array}{c}\text { R } \\
\text { Square }\end{array}$ & $\begin{array}{c}\text { Konst } \\
\text { anta }\end{array}$ & $\begin{array}{c}\text { Koefisien } \\
\text { Regresi }\end{array}$ & Sig & $\boldsymbol{\alpha}$ \\
\hline Disiplin Kerja & 0,655 & 15,639 & 0,705 & 0,000 & 0.05 \\
\hline Pengujian Signifikan & & & & \\
\hline t hitung > t tabel = 11,762 > 1,993 & & & \\
\hline Keterangan: Variabel Kepuasan Kerja \\
Sumber : data diolah 2020
\end{tabular}


Berdasarkan Tabel 4, nilai koefisien determinasi $\left(\mathrm{R}^{2}\right)$ sebesar 0.655 , artinya disiplin kerja memberikan kontribusi sebesar $65,5 \%$ kepada kepuasan kerja karyawan PT Astra International Tbk Daihatsu, Tbk Cabang Narogong, sedangkan sisanya sebesar 34,5\% disumbangkan faktor lain yang tidak diteliti, seperti kompensasi.

$$
\text { Persamaan Regresi } \mathrm{Y}=15,639+0,705\left(\mathrm{X}_{2}\right)
$$

Disiplin kerja berpengaruh positif dan signifikan pada tingkat nyata $99 \%$ terhadap kepuasan kerja karyawan PT Astra International Tbk Daihatsu, Tbk Cabang Narogong. Koefisien disiplin kerja sebesar 0,705, artinya jika ada peningkatan disiplin kerja satu kali, maka kepuasan kerja karyawan PT Astra International Tbk Daihatsu, Tbk Cabang Narogong akan meningkat sebesar 0,705 kali atau sebaliknya. Nilai t hitung $>\mathrm{t}$ tabel $(11.762>1,993)$, maka Ho tolak, Ha terima, artinya ada pengaruh yang positif dan signifikan disiplin kerja terhadap kepuasan kerja karyawan.

\section{Analisis Regresi Linear Berganda}

Tabel 6. Pengaruh Kompensasi dan Disiplin Kerja Terhadap Kepuasan Kerja

\begin{tabular}{lcccc}
\hline \multirow{2}{*}{ Variabel } & $\mathbf{4}$ Parameter \\
\cline { 2 - 5 } & Square & Konstanta & $\begin{array}{c}\text { Koefisien } \\
\text { Regresi }\end{array}$ & Sig. \\
\hline Kompensasi & 0,746 & 10,858 & 0,577 & 0,000 \\
Disiplin Kerja & & & 0,336 & 0,000 \\
\hline
\end{tabular}

\begin{tabular}{l} 
Pengujian Signifikan \\
\hline F hitung $>$ F tabel $=105,769>3,124$ \\
\hline
\end{tabular}

Keterangan: Variabel Kepuasan Kerja

Sumber : data diolah 2020

Hasil pengolahan data membuktikan, bahwa ternyata sinergi kompensasi dan disiplin kerja mampu memberikan kontribusi yang kuat, positif, dan signifikan terhadap kepuasan kerja karyawan PT Astra International Tbk Daihatsu, Tbk Cabang Narogong. Berdasarkan Tabel 6, Nilai F hitung > F tabel $(105,769>3,124)$, maka Ho tolak, Ha terima, artinya ada pengaruh yang positif dan signifikan kompensasi dan disiplin kerja terhadap kepuasan kerja karyawan PT Astra International Tbk Daihatsu, Tbk Cabang Narogong. Nilai koefisien determinasi $\left(\mathrm{R}^{2}\right)$ sebesar 0.746 , artinya kompensasi dan disiplin kerja secara bersama-sama memberikan kontribusi sebesar 74,6\% kepada kepuasan kerja karyawan PT Astra International Tbk Daihatsu, Tbk Cabang Narogong, sedangkan sisanya sebesar 25,4\% disumbangkan faktor lain yang tidak dibahas dalam penelitian ini.

$$
\text { Persamaan Regresi } \mathrm{Y}=10,858+0,577\left(\mathrm{X}_{1}\right)+0,336\left(\mathrm{X}_{2}\right)
$$

Kompensasi dan disiplin kerja berpengaruh positif dan signifikan terhadap kepuasan kerja karyawan PT Astra International Tbk Daihatsu, Tbk Cabang Narogong pada tingkat nyata $99 \%$. Koefisien kompensasi sebesar 0,577, artinya jika ada peningkatan kompensasi satu kali, maka kepuasan kerja karyawan PT Astra International Tbk Daihatsu, Tbk Cabang Narogong akan meningkat sebesar 0,577 kali atau sebaliknya dengan asumsi disiplin kerja 
tidak berubah. Koefisien disiplin kerja sebesar 0,336, artinya jika ada peningkatan disiplin kerja satu kali, maka kepuasan kerja karyawan PT Astra International Tbk Daihatsu, Tbk Cabang Narogong, akan meningkat sebesar 0,336 kali atau sebaliknya, dengan asumsi kompensasi tidak berubah.

\section{Pembahasan}

\section{Pengaruh Kompensasi Terhadap Kepuasan Kerja Karyawan PT Astra International Daihatsu, Tbk Cabang Narogong}

Hasil penelitian ini menunjukkan bahwa pemberian kompensasi yang besar dapat mendorong peningkatan kepuasan kerja karyawan. Hal ini dikarenakan bahwa gaji yang diterima sesuai dengan standar yang ditetapkan, upah diberikan apabila melebihi jam kerja, insentif diebrikan pada karyawan yang produktivitasnya tinggi dan diberikan dalam bentuk finansial, perusahaan memberikan asuransi BPJS kesehatan dan ketenagakerjaan, adanya fasiltas kendaraan dinas bagi pejabat dan tersedianya fasilitas antar jemput karyawan. Hasil penelitian ini sesuai dengan penelitian yang dilakukan oleh Supriyadi, et al, (2017) dan Wiyantini, (2016), yaitu menganalisis pengaruh kompensasi terhadap kepuasan kerja karyawan.

\section{Pengaruh Disiplin Kerja Terhadap Kepuasan Kerja Karyawan PT Astra International Daihatsu, Tbk Cabang Narogong}

Hasil penelitian ini menunjukkan bahwa disiplin kerja mendorong peningkatan kepuasan kerja karyawan. Hal ini dikarenakan bahwa karyawan dating lebih awal ke tempat kerja, mendapat tegoran bila terlambat dating, minta izin atasan bila meninggalkan pekerjaan, pekerjaan dikerjakan sesuai dengan rencana, karyawn diminta mengevaluasi hasil kerjanya, karyawan berani menerima resiko atas kesalahannya, mengikuti semua aturan yang berlaku, tidak mentati peraturan diberikan sanksi, memberikan informasi dengan melampirkan surat izin bila berhalangan hadir kerja. Hasil penelitian ini sejalan dengan penelitian yang dilakukan oleh Mustafa, (2015) dan Afriyadi, et al, (2016). yaitu menganalisis pengaruh disiplin kerja terhadap kepuasan kerja karyawan.

\section{Pengaruh Kompensasi dan Disiplin Kerja Terhadap Kepuasan Kerja Karyawan PT Astra International Daihatsu, Tbk Cabang Narogong}

Berdasarkan hasil analisis diketahui bahwa kompensasi dan disiplin kerja mendorong peningkatan kepuasan kerja karyawan PT Astra International Tbk Daihatsu, Tbk Cabang Narogong. Hasil penelitian ini sama dengan hasil penelitian yang dilakukan oleh Supriyadi, et al, (2017) dan Wiyantini, (2016), dan Mustafa, (2015) dan Afriyadi, et al, (2016), yaitu menganalisis pengaruh kompensasi dan disiplin kerja terhadap kepuasan kerja karyawan.

\section{KESIMPULAN DAN SARAN}

\section{Kesimpulan}

Penelitian yang dilakukan terhadap 55 responden di Kospin Jasa ini memberikan hasil mengenai pengaruh citra koperasi dan kualitas pelayanan yang mempengaruhi kepuasan anggota Kospin Jasa, maka diperoleh kesimpulan penelitian sebagai berikut: 1). Kompensasi berpengaruh positif dan signifikan terhadap kepuasan kerja karyawan PT. Astra International Daihatsu, Tbk Cabang Narogong. 2). Disiplin kerja berpengaruh positif dan signifikan terhadap kepuasan kerja karyawan PT. Astra International Daihatsu, Tbk Cabang Narogong. 3). Kompensasi dan disiplin kerja berpengaruh signifikan terhadap 
kepuasan kerja karyawan PT. Astra International Daihatsu, Tbk Cabang Narogong.

\section{Saran}

Dari penelitian yang penulis lakukan dan keterbatasan yang ada, maka penulis memberikan beberapa saran untuk berbagai pihak, yaitu: 1). Berkatian dengan kompensasi, berikan upah/gaji yang lebih baik lagi agar bertambah meningkatkan kepuasan kerja karyawan dan hargai ketrampilan kerja karyawan terkait pekerjaannya. 2). Kaitan dengan disiplin kerja, harus bekerja selalu tepat waktu, baik itu jam masuk, istirahat dan jam pulang, selalu berhati-hati dalam menggunakan peralatan kantor sehingga peralatan kantor terhindar dari kerusakan. 3). Bagi peneliti selanjutnya dapat menambah variabel lain yang dapat mempengaruhi kepuasan kerja karyawan, seperti lingkungan kerja dan motivasi kerja.

\section{DAFTAR PUSTAKA}

Afriyadi, Moch Andry dan Nuryanti, B. Lena. 2016., "Gambaran Disiplin Kerja, Kompensasi dan Kepuasan Kerja Karyawan PDAM Tirta Berkah Kabupaten Pandegelang". Journal of Business Management Education, Volume 1, Numbear 2, August 2016, page. 75-80.

Handoko, T. Hani. 2012. Manajemen Personalia dan Sumber Daya Manusia. Yogyakarta: BPFE.

Hasibuan, Malayu S. P. 2013. Manajemen Sumber Daya Manusia. Jakarta: PT. Bumi Aksara.

Kreitner Robert dan Kinicki Angelo. 2014. Perilaku Organisasi. Edisi 9. Buku Ke 2, Jakarta: Salemba Empat

Luthans, Fred. 2012. Perilaku Organisasi. Yogyakarta: Penerbit Andi.

Moekijat. 2010. Manajemen Sumber Daya Manusia. Cetakan Kesembilan. Bandung: Mandar Maju.

Moenir, H.A.S. 2014. Manajemen Pelayanan Umum Di Indonesia. Jakarta: Bumi Aksara.

Mustafa, Deden Rusdy. 2015. "Pengaruh Kompensasi dan Disiplin Kerja Terhadap Kepuasan Kerja Serta Implikasinya Kepada Kinerja Dosen di Sekolah Tinggi Pariwisata Bandung". Barista, Volume 2. Nomor 2. Desember 2015. Hal. 264-281.

Nitisemito, Alex S., 2010. Manajemen Personalia Manajemen Sumber Daya Manusia. Edisi Ketiga. Jakarta : Ghalia Indonesia

Notoatmodjo, Soekidjo. 2009. Pengembangan Sumber Daya Manusia. Jakarta: Rineka Cipta.

Rivai, Veithzal. 2011. Manajemen Sumber Daya Manusia untuk Perusahaan: dari Teori ke Praktik. Jakarta : Raja Grafindo Persada.

Robbins, Stephen P. \& Timothy, A. Judge . 2008. Perilaku Organisasi. Jakarta: Salemba Empat.

Saydam, Gouzaly. 2011. Manajemen Sumber Daya Manusia. Jakarta: Gunung Agung.

Sedarmayanti. 2017. Manajemen Sumber Daya Manusia. Bandung: Refika Aditama.

Simamora, Henry. 2012. Manajemen Sumber Daya Manusia. Edisi 1. Yogyakarta: STIE YKPN Yogyakarta.

Sugiyono. 2016. Statikstika Untuk Penelitian. Bandung: Alfabeta.

Supriyadi, Moch. FAchri,. Priadana, Sidik dan Setia, Bayu Indra. 2017. “Kompensasi dan Disiplin Kerja Terhadap Kepuasan Kerja Karyawan di Restoran Kampoeng Daun Kabupaten Bandung Barat". Jurnal Riset Bisnis dan Manajemen (JRBM), Volume 10, No. 2, Agustus 2017, Hal. 24-33, ISSN 1979-0600 (print), 2580-9539 (online).

Sutrisno, Edy. 2011. Manajemen Sumber Daya Manusia. Jakarta: Kencana. 
Umar, Husein. 2011. Riset Manajemen Sumber Daya Manusia dan Organisasi. Jakarta: PT. Gramedia Pustaka Utama.

Wibowo. 2011. Manajemen Kinerja. Jakarta: PT. Raja Grafindo Persada.

Wiyantini, Febrina Defin. 2016. "Pengaruh Kompensasi dan Disiplin Kerja Terhadap Kepuasan Kerja Karyawan PT. Perkebunan Nusantara X Kebun Kertosari Jember”. Jurnal Fakultas Ekonomi Universitas Muhammadiyah Jember: Agustus 2016. Hal. $1-13$.

Yani, M. 2012. Manajemen Sumber Daya Manusia. Jakarta: Mitra Wacana Media. Skripsi. 